\title{
Перші результати застосуваня мультимодальної анестезії при оперативних втручаннях на органах грудної клітки
}

\begin{abstract}
Мета роботи: продемонструвати один із варіантів збалансованої анестезії при виконанні оперативних втручань на органах грудної клітки.

Матеріали і методи. В дослідженні опрацьовано 152 випадки аналгезії, які розділено на три групи: основна - 85 пацієнтів (запропонована методика) та дві групи порівняння по 37 та 30 хворих, відповідно. Оперативні втручання на органах грудної клітки виконують при однобічній ШВЛ (інтубація правого чи лівого головних бронхів), яку досягли шляхом інтубації ендотрахеальною трубкою № 7 - № 7,5 на usb-SMART камері, приєднаній до електронних засобів візуалізації (в нашому випадку ноутбук). ШВЛ проводили за допомогою апарата “Blizar” в режимі контрольованої апаратної вентиляції (CMV). Після завершення основних хірургічних маніпуляцій ЕТТ переводили у трахею і ШВЛ проводили у звичному режимі. В період з 01.01.19 р. по 22.05.19 р. проведено 85 оперативних втручань за даною методикою (основна група). Групу порівняння склали 30 пацієнтів, оперативне втручання яким виконано за загальноприйнятою методикою тотальної внутрішньовенної анестезії з ШВЛ (використання фентанілу), третя група - фентаніл + парацетамол + лідокаїн (37 випадків). Ускладнень в кожній з груп не було.

Результати досліджень та їх обговорення. Сучасний розвиток анестезіології дає можливість для використання різних методів аналгезії. Більшість оперативних втручань на органах грудної клітки належить до складних, небезпечних, високотравматичних. Для забезпечення кращих умов виконання оперативного втручання у 80 - 90 \% випадків виконується однобічна інтубація одного з головних бронхів, що вимагає від анестезіолога ретельнішого контролю глибини аналгезії та показників життєдіяльності. Останнім часом з'являється багато інформації щодо мультимодальної аналгезії, проте більшість публікацій - це використання iї для купірування післяопераційного болю. В доступній нам літературі ми не знайшли інформації про використання мультимодальної аналгезії під час оперативного втручання. У сучасних умовах додатково слід враховувати фінансовий аспект - адже одна ампула наркотичного анальгетика (приклад - фентаніл) в 2,5 - 3 рази дорожча, ніж одна ампула НПзП (приклад налбуфін 10 мг). Це дає можливість активно і пролонговано використовувати його в поєднані з парацетамолом для купірування болю в післяопераційний період.
\end{abstract}

Ключові слова: мультимодальна анестезія; седація; наркоз.

Постановка проблеми та аналіз останніх досліджень і публікацій. Оперативні втручання на органах грудної клітки на сучасному етапі розвитку хірургії стають дедалі тривалішими та розширенішими. Захистити пацієнта від операційної травми та хірургічного стресу вдається за використання мультимодальної анестезії. Ї̈̈ використання дозволяє блокувати больові імпульси на різних рівнях їх сприйняття та проведення. Невід'ємною частиною інтенсивної терапії таких пацієнтів $\epsilon$ продовжена перидуральна аналгезія, використання якої зменшує больовий синдром, оптимізує роботу дихання та адаптацію пацієнта до ШВЛ, покращує кашель та стимулює перистальтику. Негативним ефектам перидуральної блокади вдається запобігти, якщо утримувати пацієнта в стані нормоволемії. Перидуральна аналгезія зменшує концентрацію в крові прозапальних цитокінів та нівелює прояви синдрому системної запальної відповіді [1], зменшує вирогідність метастазування в онкологічних пацієнтів, що оперовані [2]. Ревью 2016 р. вказує на те, що торакальна епідуральна аналгезія спричиняє спланхнічну вазодилатацію, покращує перфузію слизової оболонки кишечни- ка та підвищує інтрамукозальний рН у пацієнтів із перитонітом [3]. При використанні комбінованих методик анестезії визначено опіоїд-зберігаючий ефект перидуральної анестезії [4]. Епідуральна аналгезія є складовою частиною протоколів ERAS [5]. Однак встановлення перидурального катетеру зумовлює певні ризики, зокрема в пацієнтів із коагулопатією, хто отримує антикоагулянти, має анатомічні особливості та захворювання хребтового стовпа. Оскільки таких пацієнтів стає більше (наприклад, внаслідок розвитку інтервенційної кардіології збільшилась кількість пацієнтів із стентами та багатокомпонентною антикоагулянтною терапією) зростає потреба пошуку альтернативних методик аналгезії. Подібні ефекти характерні внутрішньовенній продовженій інфузії лідокаїну. Лідокаїн являє собою амідний місцевий анестетик, якому властиві анальгетична, антигіпералгетична та протизапальна дії [6]. Анальгетичний ефект розвивається завдяки супресії спонтанної генерації імпульсів ушкодженими нервовими волокнами, внаслідок блокади натрієвих каналів, калієвих каналів, мускаринових та допамінових рецепторів. Також місцевим анестетикам, зокрема лідокаїну властиві 
антиаритмічний (блокада натрієвих каналів провідникової системи серця), антитромботичний (гальмування агрегації тромбоцитів за рахунок обмеження входу кальцію в клітину), протизапальний ефект - внаслідок інгібіції мігрування та дегрануляції лейкоцитів, що також зумовлено блокадою нейрональної трансмісії, а також ефект запобігання центральній сенситизації (оскільки не відбувається вивільнення цитокінів та запальної реакції на рівні тканин), антибактеріальний та нейропротективний ефекти [6]. Якщо бупівакаїну та ропівакаїну характерні зниження кліренсу, що асоційовані із віком пацієнта, лідокаїн не має подібних властивостей і може призначатися в групі людей похилого віку [7]. Рекомендовані режими використання лідокаїну пов'язані із низькою токсичністю прпарату та становлять 1,5 мг/кг болюсно протягом 20 хвилин із наступною інфузією в дозі 1,5 мг/кг/годину протягом однієї - трьох діб [8].

Мета роботи: продемонструвати один із варіантів збалансованої анестезії при виконанні оперативних втручань на органах грудної клітки.

Матеріали і методи. При мультимодальному знеболюванні використовують два або більше аналгетики, які діють за різними механізмами для досягнення оптимального знеболювального ефекту, без збільшення вірогідності розвитку побічних реакцій при збільшені дози препарату.

У дослідженні опрацьовано 152 випадки аналгезії, які було розділено на три групи: основна 85 пацієнтів (запропонована методика) та дві групи порівняння - 37 та 30 хворих, відповідно (опис далі). Премедикацію виконували за загальноприйнятою методикою. Після катетеризації периферичної вени за 15-20 хв до початку анестезії внутрішньовенно (в/в) краплинно вводили 1000 мг парацетамолу (100 мл розчин) [9]. Ввідний наркоз складався 3 налбуфіну 10 мг, атракуріуму 5060 мг та тіопенталу натрію 500-700 мг.

Оперативні втручання на органах грудної клітки проводили при однобічній ШВЛ (інтубація правого чи лівого головних бронхів), яка досягалась шляхом інтубації ендотрахеальною трубкою № 7 - № 7,5 на usb-SMART камері, приєднаний до електронних засобів візуалізації (в нашому випадку ноутбук). ШВЛ проводили апаратом "Blizar" в режимі контрольованої апаратної вентиляції (CMV). Дихальний об’єм 300-350 мл, ХОД 7,58 л/хв. Внутрішньовенно вводили лідокаїн в дозі 80-120 мг (1-1,5 мг/кг), розведений на 100 мл фізіологічного розчину протягом 30 хв [10].

Основний наркоз дипрофолом (препарат вводили в/в краплинно згідно з інструкцією із застосування 4-10 мг(кг)/год) [11], з періодичним введенням налбуфіну через 20-30 хв у дозі 0,25-0,5 мг/кг [12]. Максимальна доза, яку ми вводили під час операції тривалістю 3,5 год - 14 мл. Релаксацію підтримували атракуріумом в дозі 0,1-0,2 мг/кг.

Після завершення основних хірургічних маніпуляцій ЕТТ переводили у трахею і ШВЛ проводилась у звичному режимі. Після закінчення оперативного втручання в/в краплинно вводили гліятон 5 мл на 50 мл 0,9 \% розчину натрію хлориду.

Декурарезація включала: атропін 1мг, прозерин 1,5-2 мг. Вкрай рідко вводили 0,2-0,3 мл налоксону. Екстубація при відновленні дихання, свідомості і м'язовому тонусі. В період з 01.01.19 р. по 22.05.19 р. проведено 85 оперативних втручань за даною методикою (основна група). Групу порівняння склали 30 пацієнтів, оперативне втручання яким виконано за загальноприйнятою методикою тотальної внутрішньовенної анестезії 3 ШВЛ (з використанням фентанілу в якості анальгетика), третя група - поєднання фентанілу, парацетамолу та лідокаїну (37 випадків). Ускладнень в кожній з груп не було.

Приклад. Пацієнтка О., 1966 р.н., госпіталізована 04.02.19 р.; зріст - 160 см; вага - 85 кг. Діагноз попередній: кіста перикарда. 07.02.19 р. виконано відеоасистоване торакоскопічне видалення кісти перикарда зліва. Дренування плевральної порожнини за Бюлау.

Обстеження: спірограма - без патології; ЕКГ норма. Ехокардіографія патології міокарда та вади серця не виявлено. АT - 120/80; PS - 78 за /хв. Комп’ютерна томографія - лівобічна перикардіальна кіста. ЗАК - Ер-4,Зт/л; Нв-132г/л; к. П.-0,92; Ht0,39; лейкоцити -7,9 г/л; ШОЕ-2,0мм/год; тромбоцити-267 г/л, глюкоза крові - 4,7 ммоль/л. Група крові - A(II); Rh - позитивна. АЧТЧ - 37,2 с; ЗАС - норма. Білірубін заг. - 9,06 ммоль/л; непрямий 9,06 ммоль/л; К - 5,2 ммоль/л; Na - 143 ммоль/л; CL - 105 ммоль/л; сечовина - 4,5 ммоль/л.

Оперативне втручання проводили під ендотрахеальним наркозом. Венепункція в правому ліктьовому згині. Моніторний нагляд. За 15 хв до початку анестезії в/в краплинно вводили 1000 мг парацетамолу.

Ввідний наркоз: налбуфін 10 мг - атракуріум 50 мг - тіопенталу натрію 500 мг в/в, краплинно підключено лідокаїн 80 мг на 100 мг фізіологічного розчину протягом 30 хв від початку анестезії. Інтубація правого бронха під контролем Smartкамери, під’єднаної до ноутбука.

Основний наркоз - дипрофол 40 мг на 400 мл фізіологічного розчину з додатковим введенням налбуфіну 40 мг та 20 мг через 30хв. ШВЛ апаратом "Blizar". ДО-320 мг. ХОД-7,5л/хв. Режим вентиляції-CMV. O ${ }_{2}-4 л /$ хв. Sa $\mathrm{O}_{2}-97-99 \%$. Су- 
марна доза атракуріума - 8 мл. PS - 74-88 за хв. АТ - 80/50 - 120/70 мм рт. ст.

Тривалість операції - 55 хв; тривалість анестезії - 1 год. Перед екстубацією вводили 5 мл гліятону на 50 мл 0,9 \% розчину натрію хлориду краплинно. Декураризація - атропін 0,1 \%-1,0, прозерин 0,05 \%-2,0 мл. Екстубація при відновленому самостійному диханні, свідомості та м'язового тонусу. Пацієнт переведений в післяопераційну палату.

Результати досліджень та їх обговорення. Сучасний розвиток анестезіології дає можливість використання різних методів аналгезії. Більшість оперативних втручань на органах грудної клітки складні, небезпечні, високотравматичні. Для забезпечення кращих умов виконання оперативного втручання 80 - 90 \% випадків виконується однобічна інтубація одного з головних бронхів, що вимагає від анестезіолога ретельнішого контролю глибини аналгезії та показників життєдіяльності. Останнім часом з’являється багато інформації щодо мультимодалної аналгезії, проте більшість публікацій - це використання її для купірування післяопераційного болю. В доступній нам літературі ми не знайшли інформації про використання мультимодальної аналгезії під час оперативного втручання. Додатково слід враховувати, в сучасних умовах, фінансовий аспект - адже одна ампула наркотичного анальгетика (приклад - фентаніл) в 2,5 - 3 рази дорожча, ніж одна ампула

\section{СПИСОК ЛІТЕРАТУРИ}

1. Perera M. R. S. Analgesia in patients with acute pancreatitis: a cry for help / M. R. S. Perera, M. Z. Tattersall, A. P. Wysocki // Journal of Gastroenterology Research and Practice. - 2014. - P. 1-10.

2. Grandhi R. K. The relationship between regional anesthesia and cancer: a metaanalysis / R. K. Grandhi, S. Lee, A. Abd-Elsayed // Ochsner Journal. - 2017. - Vol. 17 (4).- P. 245-361.

3. Thoracic epidural analgesia: a new approach for the treatment of acute pancreatitis? / O. Windisch, C. P. Heidegger, R. Giraud [et al.] // Crit. Care. -2016.- May 4. - Vol. 20 (1). - P. 116.

4. Pain management in acute pancreatitis / S. Schorn, G. O. Ceyhan, E. Tieftrunk [et al.] // American Pancreatic Association. - May 30. - 2015.

5. Role of epidural analgesia within an ERAS program after laparoscopic colorectal surgery: a review and mea - analysis of randomized controlled studies / G. Borzellino, N. K. Francis, O. Chapuis [et al.] // Surgery Research Practice. - April 2016.

6. Овечкин А. М. Клиническая фармакология местных анестетиков: классические представления и новые перспективы при-

\section{REFERENCES}

1. Perera, M.R.S. \& Wysocki A.P.(2014) Analgesia in patients with acute pancreatitis: a cry for help. Journal of Gastroenterology Research and Practice, 4, 20 (1), 1-10.
НПЗП (приклад - налбуфін 10 мг). Це дає можливість активно і пролонговано використовувати його в поєднані з парацетамолом для купірування болю в післяопераційний період. До впровадження описаного типу мультимодальної анестезії призначала фентаніл за загальноприйнятою методикою. На етапі впровадження порівнювали аналгезію фентанілом (стандартна - 30 випадків), фентаніл + парацетамол + лідокаїн (37 випадків) та налбуфіні + парацетамол + лідокаїн (85 випадків). У випадку фентаніл + парацетамол + лідокаїн зменшувалось використання наркотичних анальгетиків на 30-50 \% від розрахункових доз, в останній групі наркотичні анальгетики не використовували взагалі. Ввідний наркоз, основний наркоз, вихід із наркозу, глибина та сила седації істотної різниці за групами не мали. Зрідка спостерігали незначні коливання артеріального тиску, що пов'язуємо з маніпуляціями на органах межистіння та нефізіологічним положенням тіла (на боці) під час аналгезії.

Висновки. Враховуючи наші попередні результати, встановлено, що використання запропонованої схеми аналгезії дає можливість не застосовувати наркотичні анальгетики без втрати якості аналгезії. Просимо наукову спільноту обговорити та впровадити в практичній діяльності варіант аналгезії без використання наркотичних засобів. Будемо вдячні за конструктивну критику.

менения в интенсивной терапии / А. М. Овечкин // Регионарная анестезия и лечение острой боли. - 2013. - T. VII, № 3. - C. 6-15. 7. Intraoperative intravenous lidocaine reduses hospital length of stay following open gastrectomy for stomach cancer in man / Jin Gu Kang, Myung Hee Kim, Eun Hee Kim, Sang Hyun Lee // Journal of Clinical Anesthesia. - 2012. - No. 24. - P. 465-470.

8. Наказ МОЗ України від 16.03.2016 р. № 195 : Інструкція для застосування лікарського засобу анапірон, реєстраційне посвідчення № UA/14971/01/01.

9. Наказ МОЗ України від 03.07.2014 р. № 460 : Інструкція для застосування лікарського засобу лідокаїн, реєстраційне посвідчення № UA/0655/01/01.

10. Наказ МОЗ України від 24.01.2018 р. № 123 : Інструкція для застосування лікарського засобу дипрофол, реєстраційне посвідчення № UA/12758/01/01.

11. Наказ МОЗ України від 25.06.2015р. № 382 : Інструкція для застосування лікарського засобу налбуфін, реєстраційне посвідчення № UA/14429/01/01. 
3. Windisch, O., Heidegger, C.P., Giraud, R., Morel, P., \& Bühler, L. (2016). Thoracic epidural analgesia: a new approach for the treatment of acute pancreatitis? Crit. Care, 4, 20 (1), 116.

4. Schorn, S., Ceyhan, G.O., Tieftrunk, E., Friess, H., \& Ekin, D.I. (2015). Pain management in acute pancreatitis. American Pancreatic Association, 30, 1-13

5. Borzellino, G., Francis, NK, Chapuis O., Krastinova, E., Dyevre, V. \& Genna M. (2016). Role of epidural analgesia within an ERAS program after laparoscopic colorectal surgery: a review and mea - analysis of randomized controlled studies. Surgery Research Practice, 1-9

6. Ovechkin, A.M.(2013).Klinicheskaya farmakologiyamestnyh anestetikov: klassicheskie predstavleniya i novye perspektivy primeneniya $\mathrm{v}$ intensivnoy terapii [Clinical pharmacology of local anesthetics: classic ideas and new prospects for use in intensive care]. Regionarnaya anesteziya i lechenie ostroy boli - Regional Anesthesia and Treatment of Acute Pain, 7, 3, 6-15 [in Russian] 7. Kang, J.G., Kim, M.H., Kim, E.H., \& Lee, S.H. (2012). Intraoperative intravenous lidocaine reduses hospital length of stay following open gastrectomy for stomach cancer in man. Journal of Clinical Anesthesia, 24, 465-470.

8. Nakaz MOZ Ukrainy vid 16.03.2016 r. № 195 Instruktsiia dlia zastosuvannia likarskoho zasobu anapiron, reiestratsiine posvidchennia № UA/14971/01/01[Ministry of Health of Ukraine Order No. 195 of March 16, 2016, Instructions for the use of lidocaine,Registration Certificate No. UA/14971/01/01.]. [in Ukrainian] 9. Nakaz MOZ Ukrainy vid 03.07.2014 r. № 460 Instruktsiia dlia zastosuvannia likarskoho zasobu lidokain, reiestratsiine posvidchennia № UA/0655/01/01[ Ministry of Health of Ukraine Order No. 460 of July 3, 2014, Instruction for the use of lidocaine medicinal product, Registration Certificate No. UA / 0655/01/01]. [in Ukrainian]

10. Nakaz MOZ Ukrainy vid 24.01.2018 r. № 123 Instruktsiia dlia zastosuvannia likarskoho zasobu dyprofol, reiestratsiine posvidchennia № UA/12758/01/01 [Ministry of Health of Ukraine Order No. 123 of 24.01.2018, Instruction for use of the drug diprofol, registration certificate No. UA / 12758/01/01]. [in Ukrainian]

11. Nakaz MOZ Ukrainy vid 25.06.2015 r. № 382 Instruktsiia dlia zastosuvannia likarskoho zasobu nalbufin reiestratsiine posvidchennia № UA/14429/01/01 [Ministry of Health of Ukraine Order No. 382 of June 25, 2015, Instruction for use of nalbuphine medicinal product registration certificate No. UA / 14429/01/01]. [in Ukrainian]

Отримано 02.04.2019

Електронна адреса для листування : alkaponeyogab@gmail.com

\author{
I. V. CHUBAR, P. Y. NIKOLENKO
}

Khmelnytskyi Regional Hospital

\title{
THE FIRST RESULTS OF THE APPLICATION OF MULTIMODAL ANESTHESIA DURING SURGICAL INTERVENTIONS ON THE CHEST ORGANS
}

The aim of the work: to show one of the variants of balanced anesthesia in performing surgical interventions on the organs of the chest. Materials and Methods. The study analyzed 152 cases of analgesia, divided into three groups: the main 85 patients (proposed method) and two groups of comparison 37 and 30 cases, respectively. Operative intervention on the organs of the chest is performed with onesided mechanical ventilation (intubation of the right or left major bronchi), which was achieved by intubation with the endotracheal tube number 7 - number 7.5 on a usb-SMART camera attached to electronic visualization devices (in our case, a laptop). The ventilators were controlled by Blizar apparatus in controlled ventilation mode (CMV). After the completion of major surgical manipulations, ETT was transfused into the trachea, and mechanical ventilation was performed in the usual manner. In the period from 01.01.19. to 22.05.19 85 surgical interventions were performed according to this methodology (main group). In the comparison group, 30 patients were assigned, the surgical intervention was performed according to the common method of endotracheal analgesia with artificial ventilation (standard on fentanyl), the third group - fentanyl + paracetamol + lidocaine (37 cases). There were no complications in each of the groups.

Results and Discussion. The modern development of anesthesiology makes it possible to use different methods of analgesia. Most surgical interventions on the chest organs are complex, dangerous, and highly traumatic. To ensure better conditions for operative intervention, 80-90\% of cases are performed by one-sided incubation of one of the major bronchi, which requires more careful control of the depth of analgesia and vital signs from the anesthesiologist. Recently, there is a lot of information about multimodal analgesia, but the vast majority of publications is the use of it for the reduction of postoperative pain. In the literature available to us, we did not find information on the use of multimodal analgesia during surgical intervention. In addition, one should take into account, in modern conditions, the financial aspect - since one ampoule of narcotic analgesics (for example, fentanyl) is 2.5-3 times more expensive than one ampoule of NSAIDs (for example, nalbuphin $10 \mathrm{mg}$ ). This makes it possible to actively and prolonged use of it in conjunction with paracetamol for the purchase of pain in the postoperative period.

Key words: multimodal anesthesia; sedation; anesthesia. 


\section{ПЕРВЫЕ РЕЗУЛЬТАТЫ ИСПОЛЬЗОВАНИЯ МУЛЬТИМОДАЛЬНОЙ АНЕСТЕЗИИ ПРИ ОПЕРАТИВНЫХ ВМЕШІАТЕЛЬСТВАХ НА ОРГАНАХ ГРУДНОЙ К.ЕТКИ}

Цель работы: продемонстрировать один из вариантов сбалансированной анестезии при операциях на органах грудной клетки. Материалы и методы. В исследовании представлено 152 случая анальгезии, разделенных на три групп: основная 85 пациентов (предложенная методика) и две группы сравнения 37 и 30 случаев соответственно. Оперативные вмешательтва на органах грудной клетки проводяться при однолегочной ИВЛ (интубация правого или левого главного), которую достигали путем интубации эндотрахеальной трубкой № 7 - № 7,5 на usb-SMART камере, присоединенной к электронным средствам визуализации (в нашем случае ноутбук). ИВЛ проводили аппаратом “Blizar” в режиме контролируемой аппаратной вентиляции (CMV). После завершения основных хирургических манипуляций ЕТТ переводилась в трахею и ИВЛ проводилась в обычном режиме. В период с 01.01.19 р. по 22.05.19 р. проведено 85 оперативных вмешательств по данной методике (основная группа). В группу сравнения отнесли 30 пациентов, оперативное вмешательство которым проведено по общепринятой методике эндотрахеальной анестезии с ИВЛ (стандартная методика с использованием фентанила), третья группа - фентанил + парацетамол + лидокаин (37 случаев), осложнений в каждой из групп не было.

Результаты исследований и их обсуждение. Современное развитие анестезиологии дает возможность использования различных методов анальгезии. Большинство оперативных вмешательств на органах грудной клетки относятся к сложным, опасным, высокотравматичным. Для обеспечения лучших условий выполнения оперативного вмешательства 80 - 90 \% случаев выполняется односторонняя интубация одного из главных бронхов, требует от анестезиолога тщательного контроля глубины анальгезии и показателей жизнедеятельности. В последнее время появляется много информации о мультимодальной анальгезии, однако подавляющее большинство публикаций это использование ее для купирования послеоперационной боли. В доступной нам литературе мы не нашли информации об использовании мультимодальной анальгезии во время оперативного вмешательства. Дополнительно следует учитывать в современных условиях финансовый аспект - ведь одна ампула наркотического анальгетика (пример - фентанил) в 2,5 - 3 раза дороже чем одна ампула НПВП (пример - налбуфин 10 мг). Это дает возможность активно и пролонгировано использовать его в сочетании с парацетамолом для купирования боли в послеоперационный период.

Ключевые слова: мультимодальная анестезия; седация; наркоз. 